GLOBAL JOURNAL OF PURE AND APPLIED SCIENCES VOL. 26, 2020: 165-170 COPYRIGHTC BACHUDO SCIENCE CO. LTD PRINTED IN NIGERIA ISSN 1118-0579 www.globaljournalseries.com, Email: info@globaljournalseries.com

\title{
ANTIBACTERIAL ACTIVITIES AND PHYTOCHEMICAL SCREENING OF CRUDE EXTRACT OF CARICA PAPAYA LEAF AGAINST SELECTED PATHOGENS
}

\author{
A. E. AJIBOYE AND R. A. OLAWOYIN
}

(Received 22 June 2019; Revision Accepted 9 July 2020)

\begin{abstract}
Carica papaya commonly known as paw paw belongs to the family of Curcubitaceae and commonly grown in tropical regions. It possesses antimicrobial, antihelmintic and antioxidant properties. The study assessed the antibacterial potency of Carica papaya against Escherichia coli, Klebsiella pneumoniae and Staphylococcus aureus. Acetone and aqueous extracts of the leaves of Carica papaya were obtained using standard methods. The antibacterial activity of the extracts was done using agar well diffusion methods. The Minimum inhibitory and Minimum bactericidal concentrations were done using standard procedures. The antibacterial activities of the crude extracts of Carica papaya against the test organisms revealed that acetone extract showed maximum zone of inhibition on Staphylococcus aureus with a diameter of $17.90 \pm 0.10 \mathrm{~mm}$ at $500 \mathrm{mg} / \mathrm{ml}$ and the lowest inhibitory effect on Klebsiella pneumoniae with a zone of $6.50 \pm 0.50 \mathrm{~mm}$ at $100 \mathrm{mg} / \mathrm{ml}$, the aqueous extract showed maximum zone of inhibition on Staphylococcus aureus with a diameter of $15.50 \pm 0.50 \mathrm{~mm}$ at $500 \mathrm{mg} / \mathrm{ml}$ and the lowest zone of inhibition was on Staphylococcus aureus with a diameter of $6.50 \pm 0.50 \mathrm{~mm}$ at $100 \mathrm{~g} / \mathrm{ml}$. The Minimum Inhibitory Concentration of acetone and aqueous extract was $40 \mathrm{mg} / \mathrm{ml}$ and $50 \mathrm{mg} / \mathrm{ml}$ against Klebsiella pneumoniae respectively. The Minimum Bactericidal Concentration of the extracts ranges from $40-60 \mathrm{mg} / \mathrm{ml}$. The qualitative phytochemical screening result revealed the presence of tannins, saponnin, alkaloids and steroid. The quantitative phytochemicals revealed $0.70 \%$ of flavonoids, $0.48 \%$ of alkaloids, $1.02 \%$ of tannin, $0.11 \%$ of steroids and $1.08 \%$ of glycoside. The result obtained revealed that crude extracts of Carica papaya leaves has antibacterial activities against the test organisms.
\end{abstract}

\section{KEYWORDS: Carica papaya, Phytochemical screening, Pathogens, Antibacterial activity}

\section{INTRODUCTION}

The activities of plant extracts against bacteria have been studied for years, but with more emphasis in the last three decades. Over these years, numerous antimicrobial activities and screening evaluations have been published based on the traditional use of Chinese, African and Asian plant-based drugs (Suffredin et al. 2004).

Paw paw (Carica papaya) is commonly known for its medicinal and beneficial effect throughout the world. The medicinal properties of papaya fruit and other parts of the plant are also well known in traditional system of medicine. Each part of papaya tree possesses economic value when it is grown on a commercial scale (Karishna et al., 2008).
In recent years, the growing need for herbal products has led to a colossal rise in volume of plant materials traded across the nations. Therefore, the use and history of herbs dates to the time of early man, who had the crudest tools as his implements and used stones to start his fire. They used herbs in their raw and cooked forms to keep fit. Since that time, the use of herbs has been known and accepted by all nations and has been known also as the first art of treatment available to man (Kafaru, 1994). The use of medicinal plants has been welcome in several countries as an alternative to synthetic drugs due to their innate antimicrobial properties (Epidi et al., 2016). According to World Health Organization, close to $80 \%$ of the world population utilize medicinal plants to treat human diseases (Ayoola et al., 2010)). The main source of antimicrobial agents

\footnotetext{
A. E. Ajiboye, Microbiology Unit, Department of Biosciences and Biotechnology, College of Pure and Applied Sciences. Kwara State University, Malete, Kwara State, Nigeria. P.M.B 1530, Malete, Kwara State.

R. A. Olawoyin, Department of Science Laboratory Technology, Federal Polytechnic, Offa, Kwara State. P.M.B 420, Offa, Kwara State, Nigeria.
}

(C) 2020 Bachudo Science Co. Ltd. This work is Licensed under Creative Commons Attribution 4.0 International License. 
has been plants in recent times (Karpagam et al., 2014). Various plant structures, such as the roots, leaves, stems, and fruit have been found to possess potent compounds which enhance their antimicrobial properties. In addition, the bioactive constituents of herbal remedies have the advantage of being combined with other substances that appear to be inactive. However, these complementary components give the plant as a whole a safety and efficiency much superior to that of its isolated and pure active components (Ahmad, 2001).

Microorganisms are known to cause several infections and the uprising of multidrug resistant microbes has necessitated the use of plants as a remedy to several diseases caused by Staphylococcus aureus, Escherichia coli, Klebsiella pneumoniae amongst others causing the increase of morbidity and mortality rates (Miladi et al., 2016). The operative components inherent in these plants are expected to be inimical to the proliferation of some pathogens. Hence, this study aimed to determine the antibacterial activity and phytochemical screening of the crude extracts of Carica papaya leaf against selected pathogens such as Escherichia coli, Klebsiella pneumoniae and Staphylococcus aureus.

\section{MATERIALS AND METHODS}

\section{Collection and identification of plant materials}

The leaves of Carica papaya were obtained from Omoowo area, Offa, Kwara State, Nigeria. The plants were then duly authenticated by an ethno - botanist in the Department of Science Laboratory Technology, Federal Polytechnic Offa, Kwara State, Nigeria.

\section{Preparation of the Plant Samples}

The plant samples were carefully taken to the laboratory in separate sterile polythene bags. They were dried at room temperature for about 10 days. The dried samples were crushed into fine powder separately with a mortar and pestle.

\section{Extraction of Plant Samples}

The extraction of the plant materials was carried out using acetone and distilled water as extracting solvents. The cold maceration extraction method was used. About five hundred grams $(500 \mathrm{~g})$ of the sample (leaves of $C$. papaya) was extracted by soaking in $1000 \mathrm{ml}$ of the extracting solvents for 48 hours and 24 hours in distilled water and acetone respectively. The resulting mixtures were filtered out separately with a muslin cloth and the filtrates were evaporated to dryness with steam bath. The dried aqueous and acetone extracts were stored in sterile containers at $4^{0} \mathrm{C}$ until required for antibacterial assay.

\section{Test Organisms}

The bacteria used for this study were Staphylococcus aureus, Klebsiella pneumoniae, Escherichia coli. These organisms were obtained from Microbiology Department, University of Ilorin Teaching Hospital, Ilorin, Kwara State, Nigeria.

\section{Standardization of Microorganisms}

About $0.1 \mathrm{ml}$ of $1 \%$ Barium chloride was added to $9.9 \mathrm{ml}$ of $1 \%$ surphuric acid which was later reconstituted into $10 \mathrm{ml}$ of sterile distilled water to make $0.5 \mathrm{ml}$ Mcfarland standard solution. The broth culture of the test organism was then compared in terms of turbidity to $0.5 \%$ Mcfarland. A loopful of the standardized culture was used for antibacterial assay.

\section{Determination of Antibacterial Activities of Extracts}

The antibacterial activity of crude extract was determined by agar-well diffusion method described by Irobi et al. (1994). All test organisms were first grown in nutrient agar for 24hours before used and standardized to $0.5 \mathrm{McF}$ arland standards $\left(10^{8} \mathrm{cfu} / \mathrm{ml}\right)$. The organisms were inoculated in Mueller Hinton agar plate. Sterile cork borer of $6 \mathrm{~mm}$ was used to make wells in the Mueller Hinton agar plates. Negative and positive controls were set up. Streptomycin was used as positive control. All plates were incubated at $37{ }^{\circ} \mathrm{C}$ for 24 hours in an incubator and observed for zones of inhibition (Irobi et al., 1994)

\section{Determination of Minimum Inhibitory Concentration (MIC)}

The estimation of MIC of the plant extract was carried out by using the method of Akinpelu and Kolawole (2004). Different concentrations ranging from $40-80$ $\mathrm{mg} / \mathrm{ml}$ of the extracts were prepared and introduced into each test tube containing $9 \mathrm{ml}$ of the nutrient broth. About $1 \mathrm{ml}$ of the 18 hours standardized organism was also introduced into test tubes containing nutrient broth and extract. Control test tube was also set up. All the test tubes were incubated for 24 hours at $37{ }^{\circ} \mathrm{C}$. The least concentration of the extract that did not permit any visible growth in the broth was taken as the MIC

\section{Determination of Minimum Bactericidal Concentration (MBC)}

The MBC of the plant extracts was determined by the method of Spencer and Spencer (2004). About $1 \mathrm{ml}$ of broth was taken from the tubes with no visible growth in the MIC assay and was sub cultured on a freshly prepared nutrient agar and later incubated at $37{ }^{\circ} \mathrm{C}$ for 48 hours. The MBC was taken as the concentration of the extract that did not show any growth on a new set of agar plates.

\section{Screening Of Extracts for Qualitative Phytochemical Components \\ Test for Tannins}

Approximately $0.5 \mathrm{~g}$ of powdered sample of plant material was boiled in $20 \mathrm{ml}$ of distilled water in a test tube and then filtered. $0.1 \% \mathrm{FeCl}_{2}$ was added to the filtered sample and observed for brownish green colouration, which indicated the presence of tannins (Farnsworth, 1996)

\section{Test for Saponins}

Two grams $(2 \mathrm{~g})$ of powdered sample of the plant material was boiled together with $10 \mathrm{ml}$ of distilled water 
in a water bath and filtered, $10 \mathrm{ml}$ of the filtered sample was mixed with $5 \mathrm{ml}$ of distilled water in a test tube and shaken vigorously to obtain a stable persistent frothing which was then mixed with 3 drops of olive oil and observed for the formation of emulsion which indicates the presence of saponins (Farnsworth, 1996)

\section{Test for Cardiac Glycosides}

One millilitre $(1 \mathrm{ml})$ of concentrated $\mathrm{H}_{2} \mathrm{SO}_{4}$ was prepared in a test tube. $5 \mathrm{ml}$ of aqueous extract from the plant material samples was mixed with $2 \mathrm{ml}$ of glacial $\mathrm{CH}_{3} \mathrm{CO}_{2} \mathrm{H}$ containing 1 drop of $\mathrm{FeCl}_{2}$. The above mixture was carefully added to the $1 \mathrm{ml}$ of conc. $\mathrm{H}_{2} \mathrm{SO}_{4}$, so that the conc. $\mathrm{H}_{2} \mathrm{SO}_{4}$ is underneath the mixture. If glycoside is present in the sample, a brown ring will appear indicating the presence of the cardiac glycoside constituent (Farnsworth, 1996)

\section{Test for Alkaloids}

About $0.5 \mathrm{~g}$ of powdered sample of plant material was stirred with $5 \mathrm{ml}$ of $1 \%$ aqueous hydrochloric acid on a steam bath. A few drops of Dragendorff's reagent were used to treat $1 \mathrm{ml}$ of the filtrate. Turbidity or precipitation with this reagent indicates presence of alkaloids (Farnsworth, 1996)

\section{Test for Anthraquinones}

Five grams $(5 \mathrm{~g})$ of powdered sample of plant material was added to $10 \mathrm{ml}$ benzene, filtered and ammonia solution was added. A pink, red or violet colouration in the ammoniacal phase indicated the presence of anthraquinones (Farnsworth, 1996)

\section{Test for Steroid}

To about $2.0 \mathrm{ml}$ of extract, $1.0 \mathrm{ml}$ of concentrated sulphuric acid was added carefully along the sides of the test tube. A red color produced in the chloroform layers shows the presence of steroids (Farnsworth, 1996)

\section{Statistical Analysis}

The statistical analysis of the data obtained from antimicrobial activities was carried out using statistical package for social science (SPSS 25.0). Data were reported as mean \pm standard error (SE). The difference between the control and treated samples of acetone and aqueous extract of papaya leaves was determined by one-way analysis of variance (ANOVA) test (Bonferroni multiple comparison test). $\mathrm{P}<0.05$ was considered as statistically significant.

\section{RESULTS}

The results of antibacterial activity of acetone extract of Carica papaya are shown in Table 1. The three organisms exhibited varying degree of antibacterial activities using the acetone extract with Staphylococcus aureus having the highest activity with a diameter of zone of inhibition $17.90 \pm 0.10 \mathrm{~mm}$ at $500 \mathrm{mg} / \mathrm{ml}$ concentration and the lowest activity was Klebsiella pneumoniae with a diameter of zone of inhibition $6.50 \pm 0.50$ at $100 \mathrm{mg} / \mathrm{ml}$

The results of antibacterial activity of aqueous extract of Carica papaya were shown in Table 2. The three organisms exhibited varying degrees of antibacterial activities using the aqueous extract with Staphylococcus aureus having the highest activity with a diameter of zone of inhibition $15.50 \pm 0.50 \mathrm{~mm}$ at $500 \mathrm{mg} / \mathrm{ml}$ concentration and the lowest activity was seen in Staphylococcus aureus with a diameter of zone of inhibition $6.50 \pm 0.50$ at $100 \mathrm{mg} / \mathrm{ml}$.

The results of minimum inhibitory concentration of the acetone and aqueous extracts of the plant materials on the test organisms that were sensitive to the plant extracts during determination of antibacterial activity are shown in Table 3. The minimum inhibitory concentration for the acetone and aqueous extracts for $S$. aureus ranged from $40-50 \mathrm{mg} / \mathrm{ml}$, E. coli ranged from $50-60$ $\mathrm{mg} / \mathrm{ml}$ while $\mathrm{K}$. pneumoniae ranged from $40-50 \mathrm{mg} / \mathrm{ml}$.

The result of minimum bactericidal concentration of the acetone and aqueous extracts of the plant on the test organisms are shown in Table 4. The minimum bactericidal concentration for the acetone extract for $S$. aureus was $60 \mathrm{mg} / \mathrm{ml}$ and $50 \mathrm{mg} / \mathrm{ml}$ in aqueous extract for $E$. coli it was $50 \mathrm{mg} / \mathrm{ml}$ in acetone extract there was no $\mathrm{MBC}$ in aqueous extract and $K$. pneumoniae was 40 $\mathrm{mg} / \mathrm{ml}$ in both acetone and aqueous extract.

The results of phytochemical Screening of acetone and aqueous extracts of Carica papaya are shown in Table 5. The qualitative phytochemical screening of acetone and aqueous extract of Carica papaya leaves indicate the presence of saponnin, flavonoids, tannins, alkaloids, steroids and glycosides

The results of quantitative phytochemical Screening of acetone and aqueous extracts of Carica papaya are shown in Table 6 . The quantitative analysis of phytochemical constituents of Carica papaya revealed the percentage yield of flavonoids to be $0.70 \%$, alkaloids $0.480 \%$, tannin $1.02 \%$, Steroids $0.116 \%$ and glycosides to be $1.08 \%$

Table 1: Antibacterial Activity of Acetone extract of Carica papaya leaves against selected Bacteria

\begin{tabular}{cccccc}
\hline \multicolumn{5}{c}{ Diameter of zones of inhibition $(\mathrm{mm}) /$ Test Organism } \\
Sample extract Conc. $(\mathrm{mg} / \mathrm{ml})$ S. aureus & E. coli & K. pneumoniae & Streptomycin \\
\hline Acetone & 100 & $10.00 \pm 1.00^{\mathrm{b}}$ & $9.00 \pm 1.00^{\mathrm{b}}$ & $6.50 \pm 0.50^{\mathrm{a}}$ & $13.30 \pm 0.10^{\mathrm{c}}$ \\
& 200 & $13.50 \pm 0.50^{\mathrm{c}}$ & $11.00 \pm 0.80^{\mathrm{b}}$ & $9.00 \pm 1.00^{\mathrm{a}}$ & $11.30 \pm 1.20^{\mathrm{b}}$ \\
& 300 & $15.00 \pm 1.00^{\mathrm{b}}$ & $13.50 \pm 0.50^{\mathrm{a}}$ & $12.80 \pm 0.80^{\mathrm{a}}$ & $15.20 \pm 0.40^{\mathrm{b}}$ \\
& 400 & $17.20 \pm 0.30^{\mathrm{b}}$ & $16.50 \pm 0.50^{\mathrm{a}}$ & $15.00 \pm 1.00^{\mathrm{a}}$ & $16.40 \pm 0.60^{\mathrm{a}}$ \\
& 500 & $17.90 \pm 0.10^{\mathrm{b}}$ & $17.00 \pm 0.70^{\mathrm{a}}$ & $16.90 \pm 0.30^{\mathrm{a}}$ & $18.00 \pm 0.20^{\mathrm{b}}$ \\
\hline
\end{tabular}

Values are means of two replicates \pm SEM of zone of inhibition of antibacterial activity of acetone extract of Carica papaya against selected pathogens. Values with different superscript on the same row are statistically different at $P<0.05$ 
Table 2: Antibacterial activity of aqueous extract of Carica papaya leaves against selected bacteria

\begin{tabular}{|c|c|c|c|c|c|}
\hline \multicolumn{6}{|c|}{ Diameter of zones of inhibition (mm) / Test Organism } \\
\hline \multicolumn{3}{|c|}{ Sample extract Conc.(mg/ml) S. aureus } & E.coli & K. pneumoniae & Streptomycin \\
\hline \multirow[t]{5}{*}{ Aqueous } & 100 & $6.50 \pm 0.50^{\mathrm{a}}$ & $7.50 \pm 0.50^{b}$ & $8.00 \pm 0.00^{b}$ & $12.40 \pm 0.60^{\mathrm{C}}$ \\
\hline & 200 & $8.70 \pm 0.70^{\mathrm{a}}$ & $10.50 \pm 1.00^{b}$ & $10.00 \pm 1.00^{b}$ & $11.50 \pm 0.50^{c}$ \\
\hline & 300 & $9.90 \pm 0.40^{\mathrm{a}}$ & $11.00 \pm 1.00^{b}$ & $10.50 \pm 0.50^{\mathrm{a}}$ & $13.50 \pm 0.50^{c}$ \\
\hline & 400 & $13.00 \pm 1.00^{b}$ & $12.60 \pm 1.20^{b}$ & $11.00 \pm 1.00^{\mathrm{a}}$ & $16.00 \pm 1.00^{c}$ \\
\hline & 500 & $15.50 \pm 0.50^{b}$ & $14.60 \pm 0.40^{b}$ & $12.20 \pm 1.00^{\mathrm{a}}$ & $18.50 \pm 0.50^{c}$ \\
\hline
\end{tabular}

Values are means of two replicates \pm SEM of zone of inhibition of antibacterial activity of aqueous extract of Carica papaya against selected bacteria. Values with different superscript on the same row are statistically different at $\mathrm{P}<0.05$

Table 3: Minimum Inhibitory Concentration of the Leaves Extract of Carica Papaya against Selected Pathogens

\begin{tabular}{lcl}
\hline & Extract/Concentration $(\mathrm{mg} / \mathrm{ml})$ & \\
Organism & Acetone & Aqueous \\
\hline S. aureus & 40 & 50 \\
E. coli & 50 & 60 \\
K. pneumoniae & 40 & 50 \\
\hline
\end{tabular}

Table 4: Minimum Bactericidal concentration of the leaves extract of Carica Papaya against Selected Pathogens

\begin{tabular}{lll}
\hline & Extract/Concentration $(\mathrm{mg} / \mathrm{ml})$ & \\
Test Organism & Acetone & Aqueous \\
\hline S. aureus & 50 & 60 \\
E. coli & 50 & - \\
K. pneumoniae & 50 & 50 \\
\hline
\end{tabular}

KEY: (-) = no growth

Table 5: Qualitative Phytochemical Screening of Carica papaya Leaves Extract

\begin{tabular}{|c|c|c|}
\hline Phytochemicals & Acetone & Aqueous \\
\hline Tannin & + & + \\
\hline Saponnin & + & - \\
\hline Flavonoid & + & $\overline{+}$ \\
\hline Alkaloid & + & + \\
\hline Glycoside & + & - \\
\hline Anthraquinones & - & - \\
\hline Steriods & $\overline{+}$ & $\overline{+}$ \\
\hline
\end{tabular}

$(+)$ = Present; $(-)=$ Absent

Table 6: Quantitative Phytochemical Screening of Carica papaya Leaves Extract in (\%) Extract / Quantitative Phytochemicals (\%)

$\begin{array}{lll}\text { Phytochemicals } & \text { Acetone } & \text { Aqueous } \\ \text { Flavonoid } & 0.70 \pm 0.05 & 0.50 \pm 0.05 \\ \text { Alkaloid } & 0.48 \pm 0.01 & 0.45 \pm 0.01 \\ \text { Tannin } & 1.02 \pm 0.05 & 1.00 \pm 0.05 \\ \text { Steroid } & 0.12 \pm 0.00 & 0.22 \pm 0.01 \\ \text { Glycoside } & 1.08 \pm 0.05 & 1.05 \pm 0.05\end{array}$

Values are means of two replicates \pm SEM of quantitative phytochemicals of Carica papaya against selected bacteria

\section{DISCUSSION}

The need to discover various other sources of antibiotics is a global challenge pre-occupying higher Institutions of learning, drug producing companies, and researchers, since many infectious agents are becoming resistant to synthetic drugs (Latha and Kannabiran, 2006).

Table (1\&2) shows the result for antibacterial activity of the leaf extract of Carica papaya and it revealed that both acetone and aqueous extract exhibited varying degree of antibacterial activities though with acetone extract demonstrating highest activity against the three test organisms. Both acetone and aqueous extract also showed an increasing zone of inhibition on Staphylococcus aureus, Escherichia coli and Klebsiella pneumoniae with increasing extract concentrations. The influence of solvent for extraction on the inhibitory capacity of the extract on the test organism has been reported by Al-Bayati and Sulaiman (2008). It should be pointed out that because acetone extracts exhibited more pronounced inhibition than aqueous extracts, it is an indication that solvent system plays an important role in the solubility of the bioactive component and influence 
antibacterial activity. However, the zone of inhibition for acetone was low when compared with standard drug (Streptomycin). The highest activity was recorded with streptomycin in both extract, this is because it is a standard antibiotic and it is in a pure state. However, for some concentrations of acetone extracts against the test organisms as seen in Table1, there was no significant difference between the extract and positive control. This implies that the leaf of Carica papaya has promising potentials to serve as an antibacterial agent.

Results obtained revealed that both aqueous and acetone extracts of the plant exhibited inhibitory effect on the growth of the tested microorganisms. For acetone extract, the concentration for minimum inhibition on the test organisms was lower when compared with the concentration for inhibition with the aqueous extract (Table 3). This is similar to a research carried out by Chandra et al. (2011) where antibacterial activity of Carica papaya leaf extract was tested against Staphylococcus aureus, Bacillus subtilis, Escherichia. coli, and Pseudomonas auruginosa and also the results of the study conducted by Hema et al. (2013) which showed that the acetone extracts of Carica papaya were more effective than the ethanol and aqueous extracts.

The basic parameter for the determination of antimicrobial agents with antimicrobial potential is the minimum inhibitory concentration (MIC). The MIC of the extract for Staphylococcus aureus, Escherichia coli and Klebsiella pneumoniae ranged between $40-60 \mathrm{mg} / \mathrm{ml}$ for the acetone and aqueous extract respectively.

Various chemicals such as alkaloids, tannins, saponnin, glycosides, alkaloids, oleic acid and stearic acids which are naturally present in plants have been suggested in the presence of antimicrobial activities on the plant containing them as described by Popoola et al. (2007) The presence of some of these plant secondary metabolites in a significant amount in the investigated leaves of Carica papaya may have posed its antibacterial activity (Table 5\&6). The qualitative phytochemical screening of the leaves extract of Carica papaya revealed the presence of some bioactive compounds in both extract. This is in agreement with the research work by Omidiwura (2017) while the absence of anthraquinones in the leaves as observed in this study contradicts the finding of Omidiwura (2017), but in accordance with the research work carried out by Ajani et al. (2013) and Doughari (2006). Some of these compounds are known to be biologically active and therefore aid the antibacterial activities of Carica papaya. The phytochemicals are chemical which are produced by plants either during the primary or secondary metabolism, proof of their possible health effects has not been established yet as reported by (Nwofia et al., 2012). These compounds are known to be biologically active and therefore aid the antimicrobial activities of Carica papaya. These secondary metabolites exert antibacterial activity through different mechanisms. For instance, tannin has been found to form irreversible complexes with proline rich protein as reported by Shimada (2006) which results in the inhibition of cell protein synthesis. Parekh and Chanda (2007) reported that tannins are known to react with protein to provide the typical tanning effect which is important for the treatment of inflamed or ulcerated tissues. Dharmananda (2003) reported that tannins are used for treating disorders such as diarrhea. These observations therefore support the use of leaves of Carica papaya in curing some ailment caused by the test organisms. Alkaloids were also detected in the leaves of Carica papaya, alkaloids are toxic against cells of foreign organisms. These activities have been widely studied for their potential use in the elimination and reduction of human cancer cell lines. Just et al. (1998) reported the inhibitory effect of saponins on inflamed cell and this has supported the usefulness of this plant in managing inflammation.

Table 6 shows the quantitative analysis of phytochemical constituents of Carica papaya revealed that the percentage yield of glycoside was the highest in both extract. The least percentage yield was observed in steroids in both extracts. This is in agreement with the work of Akinpelu, (2004).

\section{CONCLUSION}

The results of the study confirmed that Carica papaya has the following bioactive constitutes: glycosides, saponnin, tannins, steroids and alkaloids which make it to have valuable antibacterial activities. The acetone and aqueous extracts of Carica papaya have strong activity when used at specific concentrations against the selected microorganisms. This finding justifies the traditional uses of these plant parts for therapeutic purposes. The demonstration of antibacterial activity against the selected test organisms is an indication that the plants are a potential source for production of drugs and suggests that the plant extracts possess compounds with antibacterial properties that can be used as antibacterial agents in novel drugs for the treatment of gastroenteritis, enteric fever, wound infection and other diseases associated with the test bacteria.

\section{ACKNOWLEDGEMENT}

I acknowledge the assistance of the following people: Mr. N.O. Olanipekun; an ethno-botanist in the Department of Science Technology, Federal Polytechnic, Offa, who helped in authenticating the identity of the medicinal plants used in this work. Sincerely I also appreciate the Head of Department of Science Laboratory Technology of Federal Polytechnic, Offa, Nigeria, Dr (Mrs) C.A. Olafimihan and all technical staff of the same department for their moral support and assistance in making available the laboratory equipment and other facilities used towards the achievement and success of this work. May God Almighty provide for their needs (Amen)

\section{REFERENCES}

Ahmad, I. and Beg, A. Z., 2001. Antimicrobial and phytochemical studies on 45 Indian medicinal plants against multi-drug resistant human pathogens. J. Ethnopharm. 74: 87- 91.

Ajani, E. O., Bamisaye, F. A. and Minari J. B., 2013. Prospects of Ethnobotanical Uses of Pawpaw (Carica papaya) J. Med. Plants Studies, 1 ( 4)

Akinpelu, D. A. and Kolawole, D. O., 2004. Phytochemical and antimicrobial activity of leaf extract of Piliostigmathonningii (Schum.). Science Focus Journal.7 (4):64-70. 
Al-Bayati, F. A. and Sulaiman, K. D., 2008. In Vitro Antimicrobial activity of Salvadorapersica $L$. Extracts against Some isolated Oral pathogens in Iraq. Turk. J. Biol 57-62.

Ayoola, P. B., Adeyeye, A. and Ogunlana, B., 2010. Phytochemical and nutrient evaluation of Carica papaya (pawpaw) leaves. IJRRAS 5(3).

Chandra, G., Ghosh, A., Chatterjee, S. K. and Bhattacharjee, I., 2011. Antibacterial activities of some plant extracts used in Indian traditional folk medicine. Asian Pacific J. Tropical Biomedicine. S165-S169.

Dharmananda, S., 2003. Gallnuts and the uses of Tannins in Chinese Medicine. In: Proceedings of Institute for Traditional Medicine, Portland, Oregon.

Doughari, J. H., 2006. Antimicrobial activity of Tamarindusindica Linn. Tropical J. Pharm. Res. 5(2): 592- 603

Epidi, T. T., Nwani, C. D. and Ugorji, N. P., 2016. Prevalence of malaria in blood donors in Abakaliki Metropolis, Nigeria. Scientific Research and Essay: 3(4): 162-164

Farnsworth, N. R., 1996. Biological and phytochemical screening of plants. $\mathrm{J}$ Pharm Sci Mar; 55(3):225-76

Hema, T. A., Arya, A. S., Subha, S., John, C.R.K. and Divya, P. V., 2013. Antimicrobial activity of five south Indian medicinal plants against clinical pathogens. International Journal of Pharma and Bio Sciences. 4(1): $70-80$.

Irobi, O. N., Moo-Young, M., Anderson, W.A. and Daramola, S. O., 1994. Antimicrobial Activity of Bark Extracts of Brideliaferruginea. J. Ethnopharmacol. 43:185-190.

Just, M. J., Recio, M. C., Giner, R. M., Cueller, M. J., Manez, S., Bilia, A. R. and Rios, J. L., 1998. Anti-inflammatory activity of unusual lupine saponins from Bupleurum fruticescens. Plant Medicine. 64(2):404-407.

Kafaru, E., 1994. Immense Help from Nature's Workshop. Elika Health Services Ltd, Academic Press Plc. Lagos, Nigeria: 1-27.

Karpagam, T. and Nagalakshmi, P. K., 2014. Isolation and characterization of phosphate solubilizing microbes from agricultural soil. Int $\mathrm{J}$ Curr Microbiol App Sci 3:601-614.

Karishna, K. L., Paridhavi, M., and Patel, J. A., 2008. Review on nutritional, medicinal and pharmacological properties of papaya (Carica papaya Linn.) natural product radiance. Indian Journal of Natural Products and Resources (IJNPR); 7(4): 364-373.

Latha, S. P. and Kannabiran, K., 2006. Antimicrobial activity and phytochemicals of Solanumtrinobatum Linn. African Journal of Biotechnology; 5(23): 2402-2404.

Miladi, K., Safar, S., Fessi, H. and Elaissari, A., 2016. Nanoprecipitation Process: from particle precipitation to in vivo Applications. International J Pharm 445(1-2):181-195.

Nwofia, G. E., Ogimelukwe, P. and Eji, C., 2012. Chemical composition of leaves, fruit pulp and seed in some morphotypes of Carica papaya Leaf orphotypes. Int. J. Med. Arom. Plant 2:200206

Omidiwura, B.R.O., 2017. Qualitative and quantitative analysis of pawpaw (Carica papaya) leaf extract and its antimicrobial effect in animal production. Nig. J. Anim. Prod., 44(3):78 - 83.

Parekh, J. and Chanda, S., 2007. In vitro antibacterial activity of crude methanol extract of Woodfordia fruticosa Kurz flower (Lythacease).Brazil. Journal of Microbiology. 38(3):2.

Popoola, T. O. S., Yangomodu, O. D. and Akintokun, A. K., 2007. Antimicrobial activity of cassava seed oil on skin pathogenicmicroorganisms. Res. J. Med. Plant, 1(2): 60-64.

Shimada, T., 2006. Salivary proteins as a defense against dietary tannins. Journal Of Chemical Ecology. 32(6):1149-1163.

Spencer, T. E. and Spencer, T. N., 2004. Uterine and placental factors regulating conceptus growth in domestic animals. J Animal Science 82 ESuppl:E4-13.

Suffredin, I. B., Sarder, H. S. and Goncalves, A. G., 2004. Screening of antibacterial extracts from plants native to Brazillian amazon Rain Forest and Atlantic Forest. Brazillian J. Med. Biol. Res. $37: 379$ 